\title{
Kinetic Modeling of Cyclohexane Oxidation Including PAH Formation
}

\author{
M. Abbasi ${ }^{1}$, N.A. Slavinskaya ${ }^{2}$, U. Riedel ${ }^{3}$ \\ Institute of Combustion Technology, German Aerospace Center (DLR), Stuttgart, Germany
}

\begin{abstract}
A reaction mechanism for cyclohexane $\left(\mathrm{cyC}_{6} \mathrm{H}_{12}\right)$ is developed to study its oxidation at both low and high temperatures, including $\mathrm{PAH}$ formation. Based on values of rate coefficients available in literature, uncertainty analyses has been performed for each reaction class included in the mechanism, and the optimum values are implemented in the $\mathrm{cyC}_{6} \mathrm{H}_{12}$ sub-mechanism. Furthermore, reactions of bi-cyclic ethers and cylohexanone decompositions via further dehydrogenation steps and ring-opening leading to smaller olefins and ketone radicals were implemented. Thermochemical properties of the main species of the low-temperature sub-mechanism are determined by applying the group additivity method of Benson. The properties of some new Benson's groups, including ring corrections for cycling species were estimated. The ignition delay data from rapid compression machines (RCM) and shock tube experiments and also laminar flame speed data have been used for the model validation. The concentration profiles of the soot precursor species from burner-stabilized premixed flames experiments at different pressures and temperatures are well predicted by the current model.
\end{abstract}

\section{Introduction}

$\mathrm{C}$ YCLOALKANES (naphthenes) are an important chemical class of hydrocarbons found in diesel (up to 35\%), kerosene ( 20\%) and gasoline ( 10\%), which affects the ignition quality of the fuel. Also cycloalkanes can raise soot emission levels because they are known to dehydrogenate and produce aromatics which can initiate the chain reaction for the production of polycyclic aromatics to soot formation and growth. The combustion of cyclohexane $\left(\mathrm{CHX}, \mathrm{cyC}_{6} \mathrm{H}_{12}\right)$, the base simplest cycloalkanes, has been intensively investigated. ${ }^{1-29}$ Table 1 summarizes the data-pool used in this study to develop the reaction mechanism. It shows the conditions of key experiments $^{11-20}$ as well as the experimental setup used to obtain these data. Despite these investigations on cyclohexane oxidation, the published primary reaction classes and their reference kinetic parameters show significant discrepancies. The uncertainty factor of reaction rate coefficients, $\Delta \log (k)$, for these reaction classes can reach almost 10 .

The principal products of the cyclohexane pyrolysis were studied by Tsang in $1978^{25}$ in shock tube experiments. Ethylene, 1,3-butadiene, and 1- hexene were identified as the main pyrolysis products. One of the first studies of low temperature chemistry of $\mathrm{cyC}_{6} \mathrm{H}_{12}$ oxidation was performed by Zeelenberg and Bruijn ${ }^{26}$ which analyzed the primary products of the slow oxidation of cyclohexane during the induction period at low temperature and low pressure. A further investigation of the low temperature oxidation with extensive analyses of various reaction paths was undertaken by Klaï and Baronnet. ${ }^{27}$

In the present work the high temperature scheme is developed further through extended cascading dehydrogenation steps and the low temperature chain propagation scheme includes formation of cyclohexanone and three bicyclic ethers and their decomposition paths. The required thermochemical properties specifically for lowtemperature species, which have more complex structures, are revised and evaluated, applying Benson's additivity method with new available updates of Benson's groups ${ }^{33}$ and ring corrections.

\footnotetext{
${ }^{1}$ PhD Student, Chemical Kinetics Department, mehdi.abbasi@dlr.de.

${ }^{2}$ Senior research fellow, Chemical Kinetics Department, Nadja.Slavinskaya@dlr.de, AIAA Senior Member

${ }^{3}$ Head of department, Chemical Kinetics Department, uwe.riedel@dlr.de,AIAA Senior Member
} 
Table 1. Kinetic mechanisms and their experimental validations ${ }^{1-20}(\mathrm{ST}=$ Shock tube, $\mathrm{RCM}=$ Rapid Compression Machine, PFR = Plug Flow Reactor, JSR = Jet Stirred Reactor).

\begin{tabular}{|c|c|c|c|c|c|}
\hline \multirow{2}{*}{ Model } & \multicolumn{5}{|c|}{ Validation } \\
\hline & ST & RCM & PFR & JSR & Flame Structure \\
\hline 苞 & & & & $\begin{array}{l}\text { Concentration profile }^{\mathbf{1 3}} \\
\mathbf{T}=750-1100 \mathrm{~K}, \boldsymbol{\tau}=0.5 \mathrm{~s} \\
\mathbf{P}=10 \mathrm{~atm}, \boldsymbol{\varphi}=0.5,1.0,1.5 \\
\text { Mixture }\left(\mathbf{C H X} / \mathbf{O}_{2}\right): \\
(0.1,1.8),(0.1,0.9),(0.1,0.6) \%\end{array}$ & \\
\hline 可 & & & & $\begin{array}{l}\text { Concentration profile } \mathbf{1}^{\mathbf{1 , 1 3}} \\
\mathbf{T}=750-1200 \mathrm{~K}, \boldsymbol{\tau}=0.07-0.5 \mathrm{~s} \\
\mathbf{P}=1,2,10 \mathrm{~atm}, \boldsymbol{\varphi}=0.5,1.0,1.5 \\
\text { Mixture }\left(\mathbf{0 . 1 5} \% \mathbf{C H X} / \mathbf{O}_{2} / \mathbf{N}_{\mathbf{2}}\right)\end{array}$ & $\begin{array}{l}\text { Flame Speed }^{12} \\
\mathbf{T}=298 \mathrm{~K} \\
\mathbf{P}=1 \mathrm{~atm}\end{array}$ \\
\hline 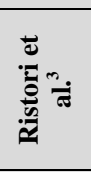 & & & ( & $\begin{array}{l}\text { Concentration profile }^{3,13} \\
\mathbf{T}=980-1200 \mathrm{~K} \\
\mathbf{P}=1 \mathrm{~atm}, \boldsymbol{\varphi}=1.0, \boldsymbol{\tau}=0.07 \mathrm{~s} \\
\text { Mixture }\left(\mathbf{F u} / \mathbf{O}_{2} / \mathbf{N}_{2}\right): \\
(0.15 / 1.35 / 98.5) \%\end{array}$ & \\
\hline 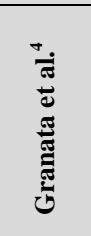 & & $\begin{array}{l}\text { Ignition delay time }^{\mathbf{1 1}} \\
\mathbf{P}_{\mathrm{TDC}}=0.7-0.9 \mathrm{Mpa} \\
\mathbf{T}=650-900 \mathrm{~K}, \boldsymbol{\varphi}=1.0 \\
\text { Mixture (CHX/ air) }\end{array}$ & $\begin{array}{l}\text { Concentration profile }{ }^{\mathbf{1 4}} \\
\mathbf{T}=1155 \mathrm{~K}, \mathbf{P}=1 \mathrm{~atm} \\
\text { Mixture }\left(\mathbf{M C H} \text { in } \mathbf{N}_{2}\right): \\
\text { MCH= } 0.166 \text { vol. } \% \\
\mathbf{T}=1160 \mathrm{~K}, \mathbf{P}=1 \mathrm{~atm} \\
\text { Mixture }\left(\mathbf{M C H} / \mathbf{O}_{2} / \mathbf{N}_{2}\right): \\
(0.185 / 1.9) \text { vol. } \%\end{array}$ & $\begin{array}{l}\text { Concentration profile }{ }^{1,2} \\
\mathbf{T}=800-1200 \mathrm{~K}, \\
\mathbf{P}=1-10 \mathrm{~atm} \\
\boldsymbol{\varphi}=0.5,1.0,1.5\end{array}$ & $\begin{array}{l}\text { Flame Speed }^{\mathbf{1 2}} \\
\mathbf{T}=298 \mathrm{~K} \\
\mathbf{P}=1 \mathrm{~atm}\end{array}$ \\
\hline ڤึ. & $\begin{array}{l}\text { Ignition delay } \\
\text { time }^{5} \\
\mathbf{T}=1050-1520 \\
\mathrm{~K}, \\
\mathbf{P}=\sim 8 \mathrm{~atm} \\
\boldsymbol{\varphi}=0.5,1.0,2.0\end{array}$ & & & & \\
\hline ฮ & & & & & $\begin{array}{l}\text { Concentration } \\
\text { profile }^{\mathbf{1 5 , 1 6}} \\
\mathbf{T}=1000 \mathrm{~K}, \\
\mathbf{P}=30 \text { Torr } \\
\boldsymbol{\varphi}=1.0,2.0\end{array}$ \\
\hline 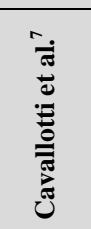 & & $\begin{array}{l}\text { Ignition delay time, } \\
\text { Concentration profile }{ }^{11} \\
\mathbf{P}_{\mathrm{TDC}}=0.7-0.9 / 1.1-1.4 \mathrm{MPa} \\
\mathbf{T}=700-1000 \mathrm{~K}, \boldsymbol{\varphi}=1.0 \\
\text { Mixture: } \mathrm{CHX} / \text { air }\end{array}$ & & $\begin{array}{l}\text { Concentration profile }^{2} \\
\mathbf{T}=800-1200 \mathrm{~K} \\
\mathbf{P}=1-10 \mathrm{~atm} \\
\boldsymbol{\varphi}=0.5,1.0,1.5\end{array}$ & \\
\hline 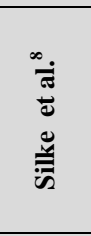 & & $\begin{array}{l}\text { Ignition delay time }^{11} \\
\mathbf{P}_{\mathrm{TDC}}=0.7-0.9 / 1.1-1.4 \mathrm{MPa} \\
\mathbf{T}=700-1000 \mathrm{~K}, \boldsymbol{\varphi}=1.0 \\
\text { Mixture }: \mathrm{CHX} / \text { air }\end{array}$ & & $\begin{array}{l}\text { Concentration profile }^{1} \\
\mathbf{T}=850-1070 \mathrm{~K}, \mathbf{P}=10 \mathrm{~atm} \\
\boldsymbol{\varphi}=0.5,1.0,1.5, \boldsymbol{\tau}=0.5 \mathrm{~s} \\
{ }^{13}:(\mathbf{T} / \mathbf{P} / \boldsymbol{\varphi} / \boldsymbol{\tau}) \\
(850-1150 \mathrm{~K} / 2 \mathrm{~atm} / 1.0 / 0.1 \mathrm{~s}) \\
(850-1150 \mathrm{~K} / 5 \mathrm{~atm} / 1.0 / 0.25 \mathrm{~s}) \\
\text { Mixture: } \mathrm{CHX} / \mathrm{O}_{2} \text { in } 99 \% \mathrm{~N}_{2}\end{array}$ & \\
\hline 突 & & $\begin{array}{l}\text { Ignition delay time } \mathbf{t i}^{\mathbf{1 1}} \\
\mathbf{P}=0.7-0.9 / 1.1-1.4 \mathrm{MPa} \\
\mathbf{T}=700-1000 \mathrm{~K}, \boldsymbol{\varphi}=1.0 \\
\text { Mixture }: \mathrm{CHX} / \text { air }\end{array}$ & & $\begin{array}{l}\text { Concentration profile }^{1} \\
\mathbf{T}=850-1070 \mathrm{~K}, \mathbf{P}=10 \mathrm{~atm} \\
\boldsymbol{\varphi}=0.5,1.0,1.5 \quad, \quad \boldsymbol{\tau}=0.5 \mathrm{~s}\end{array}$ & \\
\hline$\frac{\text { हैं }}{\text { हैं }}$ & $\begin{array}{l}\begin{array}{l}\text { Ignition delay } \\
\text { time }^{\mathbf{1 9}}\end{array} \\
\mathbf{T}=950-1200 \mathrm{~K} \\
\mathbf{P}=13-15 \mathrm{bar} \\
\boldsymbol{\varphi}=0.5,1.0\end{array}$ & $\begin{array}{l}\text { Ignition delay time }^{\mathbf{1 1}} \\
\mathbf{P}_{\mathbf{T D C}}=1.1-1.4 \mathrm{Mpa} \\
\mathbf{T}=700-1000 \mathrm{~K}, \boldsymbol{\varphi}=1.0 \\
\text { Mixture: } \mathrm{CHX} / \text { air } \\
{ }^{20} \text { : } \\
\mathbf{T}=600-900 \mathrm{~K}, \\
\boldsymbol{\varphi}=0.5,1.0,2 \\
\mathbf{P}=12.5,20,40 \text { bar } \\
\text { Mixture: } \mathrm{CHX} / \mathrm{O}_{2} \text { in } \mathrm{N}_{2} \\
\mathbf{X}_{\text {fuel }}=0.0226\end{array}$ & & $\begin{array}{l}\text { Concentration profile }^{\mathbf{1 0}} \\
\mathbf{T}=500-1100 \mathrm{~K} \\
\mathbf{P}=1.07 \text { bar }, \boldsymbol{\varphi}=0.5,1.0,2 \\
\boldsymbol{\tau}=2 \mathrm{~s}\end{array}$ & $\begin{array}{l}\begin{array}{l}\text { Flame Speed } \\
\text { (Flat- flame) }\end{array} \\
\mathbf{T}=298,358,398 \mathrm{~K} \\
\mathbf{P}=1 \mathrm{~atm} \\
{ }^{\mathbf{1 2}} \text { (Counter flow): } \\
\mathbf{T}=298 \mathrm{~K}-\mathbf{P}=1 \mathrm{~atm} \\
{ }^{17} \text { (Counter flow): } \\
\mathbf{T}=353 \mathrm{~K}-\mathbf{P}=1 \mathrm{~atm} \\
\mathbf{1 8} \text { (spherical flame): } \\
\mathbf{T}=353 \mathrm{~K}, \mathbf{P}=1-20 \text { atm }\end{array}$ \\
\hline
\end{tabular}




\section{Kinetic Model}

The reaction mechanism has been developed for high and low temperature oxidation of cyclohexane using the base model of DLR $\left(\mathrm{C}_{0}-\mathrm{C}_{4}\right.$ kinetic model ${ }^{31}$ combined with a PAH formation sub-model $\left.{ }^{31,32}\right)$. During the cyclohexane mechanism development, the generic reactions for both regimes (high and low temperature) of the cyclo-hydrocarbon oxidation are determined. The cyclohexane high temperature oxidation (Fig.1) proceeds through:

1) unimolecular fuel decomposition

2) $\mathrm{H}$-atom abstraction leading to cycloalkyl radical, $\mathrm{cyC}_{6} \mathrm{H}_{11}$

3) $\mathrm{cyC}_{6} \mathrm{H}_{11} \beta$-scission decomposition, producing olefins and di-olefins

4) cascading dehydrogenation leading to benzene and smaller radicals

5) isomerization and decomposition of linear hexenyl radicals after the ring-opening step.

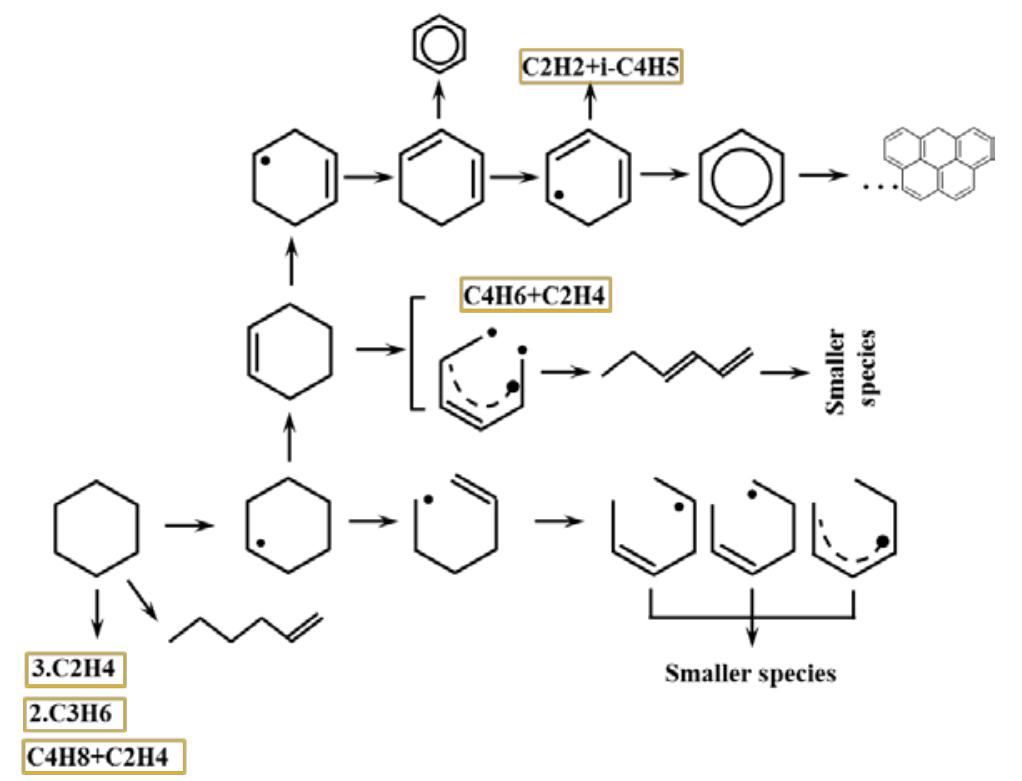

Figure 1. Principal scheme of the high temperature oxidation of $\operatorname{cyC}_{6} \mathrm{H}_{12}$.

The low temperature cyclohexane oxidation can be described with the general scheme for the low temperature oxidation of acyclic alkanes, but with the formation of intermediate species with 2 rings, specifically bi-cyclic ethers and cyclic ketones (Fig.2). The low temperature oxidation proceeds through :

1) $\mathrm{cyC}_{6} \mathrm{H}_{11} \mathrm{O} \bullet$ and cycloperoxy radical $\left(\mathrm{cyC}_{6} \mathrm{H}_{11} \mathrm{OO} \bullet\right.$ ) formation from reactions of $\mathrm{cyC}_{6} \mathrm{H}_{11} \bullet$ with $\mathrm{O}_{2}$ and $\mathrm{O} \bullet$, leading to further chain branching pathways;

2) isomerization of $\mathrm{cyC}_{6} \mathrm{H}_{11} \mathrm{OO} \bullet$ to cyclohydroperoxy radicals $\left(\mathrm{cyC}_{6} \mathrm{H}_{10} \mathrm{OOH} \bullet\right)$ through the 4-, 5-, 6-, and 7centre transition states;

3) decomposition $\mathrm{cyC}_{6} \mathrm{H}_{11} \mathrm{OO} \cdot$ radicals to cyclohexene and $\mathrm{HO}_{2}$;

4) Formation of $\mathrm{cyC}_{6} \mathrm{H}_{11} \mathrm{O} \bullet$ from $\mathrm{cyC}_{6} \mathrm{H}_{11} \mathrm{OO} \bullet$ radicals;

5) decomposition of $\mathrm{cyC}_{6} \mathrm{H}_{10} \mathrm{OOH}$ and $\mathrm{cyC}_{6} \mathrm{H}_{11} \mathrm{OO}$ - radicals to cyclohexanone, three bicyclic ethers and smaller species;

6) $\mathrm{O}_{2}$ addition to $\mathrm{cyC}_{6} \mathrm{H}_{10} \mathrm{OOH} \bullet$ with formation of $\mathrm{O}_{2} \mathrm{QOOH} \bullet$ type radicals;

7) decomposition of bicyclic ethers and cyclohexanone through dehydrogenation leading to formation of $\mathrm{cyC}_{6} \mathrm{H}_{9} \mathrm{O}$ radicals.

8) decomposition of $\mathrm{O}_{2} \mathrm{QOOH} \bullet$ to cyclic ketohydroperoxides;

9) $\mathrm{HO}_{2}$ addition to $\mathrm{cyC}_{6} \mathrm{H}_{9} \mathrm{O}$ and formation of $\mathrm{cyOC}_{6} \mathrm{H}_{9} \mathrm{OO} \bullet$ ketohydroperoxides;

10) decomposition of cyclic ketohydroperoxides $\mathrm{OQOOH}$ to hydroxyl radical and smaller species;

11) decomposition of $\mathrm{cyC}_{6} \mathrm{H}_{9} \mathrm{O} \bullet$ via ring opening to small olefin molecules and ketone radicals.

The actual uncertainty levels of the main reaction rate coefficients have been analyzed, based on the data collected from literature. On these grounds the optimum values for each reaction have been evaluated and applied in the mechanism. 


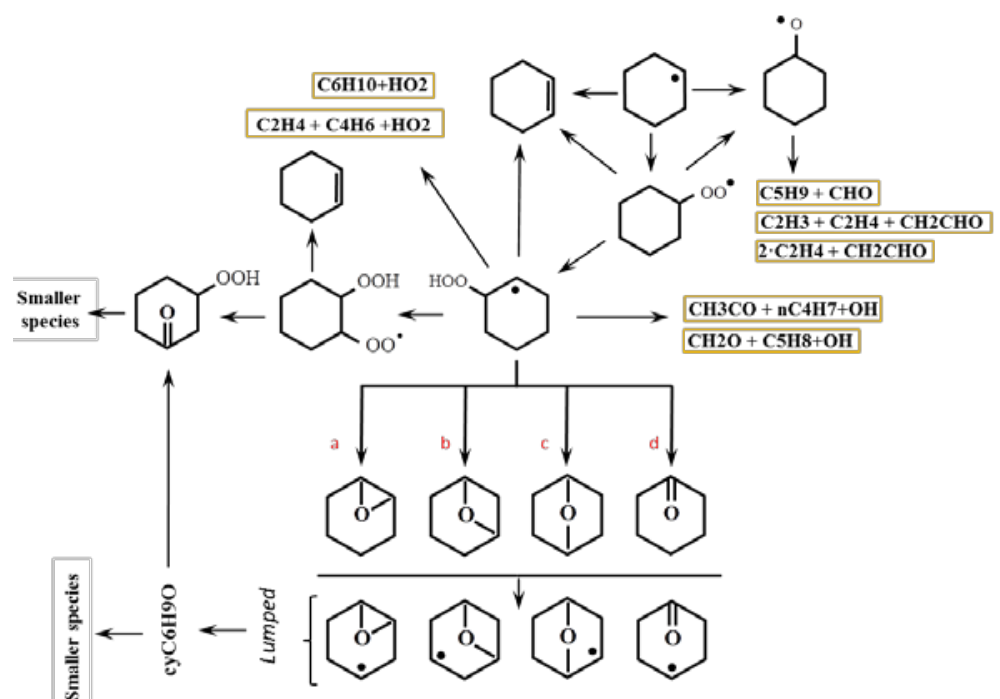

Figure 2. Principal scheme of the low temperature oxidation of $\operatorname{cyC}_{6} \mathrm{H}_{12}$.

The statistical treatment of the rate coefficient goes through certain number of available data is based on the least-squares regression. We used the non-linear least squares method and its numeric realization FUMILI. ${ }^{40}$ This linearizes model and approximates the data of " $m$ " observations with a model of " $n$ " unknown parameters $(m>n)$. The evaluation of parameters is obtained, minimizing an objective function. An in house developed tool, written by DLR (German Aerospace Center) at Stuttgart was used for this aim. Fig.3 shows an example of uncertainty estimation and analysis for one of the reactions of high temperature regime, abstracting a hydrogen atom from cyclohexane molecules by $\mathrm{O}$ atom, initiating cyclohexane radicals. Table 2 represents the applied reaction rates and calculated uncertainty factors for lower $\left(F_{l}\right)$ and upper $\left(F_{u}\right)$ boundaries. Statistical uncertainty analysis is limited to the number of available data sets (observation). Therefore this was not performed for certain reactions, due to the lack of data.

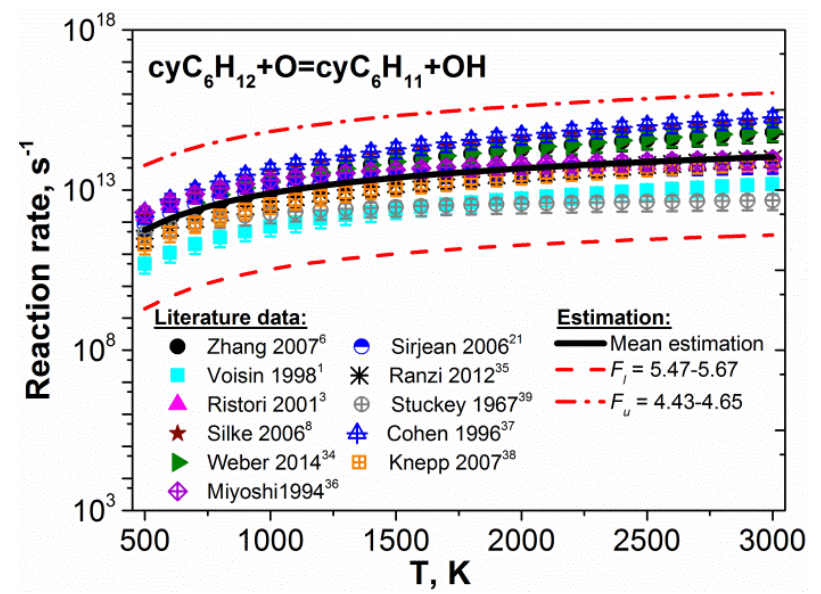

Figure 3. Uncertainty estimation and analysis of reaction rate vs. temperature, based on the available literature data for the reaction $\mathrm{cyC}_{6} \mathrm{H}_{12}+\mathrm{O}=\mathrm{cyC}_{6} \mathrm{H}_{11}+\mathrm{OH}$.

Estimation of the thermodynamic properties for certain species, including new species, was done based on the Benson's additivity method, with the updates and corrections especially for cyclic and bicyclic structures, reported in previous work of the authors. ${ }^{33}$ Approximation of the NASA-polynomial function was also done, utilizing an inhouse developed FORTRAN code, written by DLR (German Aerospace Center) at Stuttgart. The transportation properties were also extended using group contribution method of. ${ }^{43}$ 
Table 2. Reaction rate and estimated lower and upper uncertainty factors for major reaction types in high and low temperature regimes.

\begin{tabular}{|c|c|c|c|c|c|c|c|c|}
\hline Reaction $^{*}$ & Type & $\Delta \mathrm{T}, \mathrm{K}$ & $\mathbf{A}$ & $\boldsymbol{\beta}$ & $\mathbf{E}_{\mathbf{a}}$ & Ref. & $F_{I}$ & $F_{u}$ \\
\hline \multicolumn{9}{|c|}{ High temperature } \\
\hline $\mathrm{cyC}_{6} \mathrm{H}_{12}=\mathrm{cyC}_{6} \mathrm{H}_{11}+\mathrm{H}$ & DE-INT & $500-3000$ & $3.00 \mathrm{E}+16$ & 0.0 & 95000 & 3 & $-^{* *}$ & - \\
\hline $\mathrm{cyC}_{6} \mathrm{H}_{12}=>3 \mathrm{C}_{2} \mathrm{H}_{4}$ & $\mathrm{DE}$ & $500-3000$ & $8.22 \mathrm{E}+17$ & 0.0 & 87225 & 1 & $2.33-3.78$ & $0.92-2.37$ \\
\hline $\mathrm{cyC}_{6} \mathrm{H}_{12}=\mathrm{aC}_{6} \mathrm{H}_{12}$ & $\mathrm{RN}$ & $1000-3000$ & $5.01 \mathrm{E}+16$ & 0.0 & 88230 & 25 & $5.88-6.20$ & $4.85-5.17$ \\
\hline $\mathrm{cyC}_{6} \mathrm{H}_{12}+\mathrm{O}_{2}=\mathrm{cyC}_{6} \mathrm{H}_{11}+\mathrm{HO}_{2}$ & HABS-INT & $1000-3000$ & $6.00 \mathrm{E}+12$ & 0.0 & 50150.1 & 6 & $2.47-2.65$ & $2.44-2.62$ \\
\hline $\mathrm{cyC}_{6} \mathrm{H}_{12}+\mathrm{CH}_{3}=\mathrm{cyC}_{6} \mathrm{H}_{11}+\mathrm{CH}_{4}$ & HABS-INT & $500-3000$ & $1.35 \mathrm{E}+12$ & 0.0 & 9540 & 1 & $2.38-2.64$ & $2.35-2.61$ \\
\hline $\mathrm{cyC}_{6} \mathrm{H}_{12}+\mathrm{C}_{2} \mathrm{H}_{3}=\mathrm{cyC}_{6} \mathrm{H}_{11}+\mathrm{C}_{2} \mathrm{H}_{4}$ & HABS-INT & $500-3000$ & $1.35 \mathrm{E}+12$ & 0.0 & 9540 & 1 & $2.72-2.85$ & $2.63-2.76$ \\
\hline $\mathrm{cyC}_{6} \mathrm{H}_{11}=\mathrm{C}_{6} \mathrm{H}_{11}$ & $\mathrm{RN}$ & $1000-3000$ & $3.00 \mathrm{E}+12$ & 0.624 & 30810 & 28 & $2.82-2.92$ & $2.71-2.80$ \\
\hline $\mathrm{cyC}_{6} \mathrm{H}_{11}=\mathrm{cyC}_{6} \mathrm{H}_{10}+\mathrm{H}$ & BSC & $1000-3000$ & $8.91 \mathrm{E}+11$ & 0.834 & 36340 & 28 & $3.38-3.57$ & $3.07-3.26$ \\
\hline $\mathrm{cyC}_{6} \mathrm{H}_{11}+\mathrm{O}=\mathrm{C}_{5} \mathrm{H}_{9}+\mathrm{CH}_{2} \mathrm{O}$ & $\mathrm{DE}$ & $500-3000$ & $9.61 \mathrm{E}+13$ & 0.0 & 0.0 & 41 & - & - \\
\hline $\mathrm{cyC}_{6} \mathrm{H}_{11}+\mathrm{O}_{2}=\mathrm{cyC}_{6} \mathrm{H}_{10}+\mathrm{HO}_{2}$ & HABS & $700-3000$ & $1.50 \mathrm{E}+12$ & 0.0 & 4251.2 & 6 & $2.40-2.62$ & $2.38-2.60$ \\
\hline $\mathrm{cyC}_{6} \mathrm{H}_{11}+\mathrm{HO}_{2}=\mathrm{cyC}_{6} \mathrm{H}_{10}+\mathrm{H}_{2} \mathrm{O}_{2}$ & HABS & $600-3000$ & $1.00 \mathrm{E}+12$ & 0.0 & 2000 & 1 & $1.31-1.72$ & $1.29-1.70$ \\
\hline $\mathrm{cyC}_{6} \mathrm{H}_{11}+\mathrm{CH}_{3}=\mathrm{cyC}_{6} \mathrm{H}_{10}+\mathrm{CH}_{4}$ & HABS & $500-3000$ & $1.71 \mathrm{E}+13$ & 0.0 & 0.0 & generic & $1.64-1.88$ & $1.35-1.59$ \\
\hline $\mathrm{cyC}_{6} \mathrm{H}_{10}=\mathrm{cyC}_{6} \mathrm{H}_{9}+\mathrm{H}$ & $\mathrm{DE}$ & $1200-3000$ & $1.20 \mathrm{E}+15$ & 0.0 & 83200 & 5 & $3.11-3.21$ & $2.82-2.92$ \\
\hline $\mathrm{cyC}_{6} \mathrm{H}_{10}=\mathrm{C}_{4} \mathrm{H}_{6}+\mathrm{C}_{2} \mathrm{H}_{4}$ & $\mathrm{DE}$ & $1200-3000$ & $4.00 \mathrm{E}+14$ & 0.0 & 63400 & generic & $1.46-1.71$ & $1.17-1.42$ \\
\hline \multicolumn{9}{|c|}{ Low Temperature } \\
\hline $\mathrm{cyC}_{6} \mathrm{H}_{11}+\mathrm{O}_{2}=\mathrm{cyC}_{6} \mathrm{H}_{11} \mathrm{OO}$ & ADD & $700-3000$ & $8.00 \mathrm{E}+18$ & -2.5 & 0.0 & $9 a$ & $6.40-6.83$ & $6.1-6.58$ \\
\hline $\mathrm{cyC}_{6} \mathrm{H}_{11} \mathrm{OO}=\mathrm{cyC}_{6} \mathrm{H}_{10} \mathrm{OOH}$ & ISM & $800-3000$ & $1.50 \mathrm{E}+12$ & 0.0 & 24076 & $43 \mathbf{b}$ & $5.58-6.33$ & $5.53-6.29$ \\
\hline $\mathrm{cyC}_{6} \mathrm{H}_{10} \mathrm{OOH}=>\mathrm{CH}_{2} \mathrm{O}+\mathrm{C}_{5} \mathrm{H}_{8}+\mathrm{OH}$ & BSC & $900-3000$ & $2.20 \mathrm{E}+16$ & 0.0 & 22500 & $42 c$ & $4.28-4.73$ & $3.33-3.78$ \\
\hline $\mathrm{cyC}_{6} \mathrm{H}_{10} \mathrm{OOH}=\mathrm{a}-\mathrm{cyC}_{6} \mathrm{H}_{10} \mathrm{O}+\mathrm{OH}$ & DE2BCYE & $500-3000$ & $2.20 \mathrm{E}+16$ & 0.0 & 22500 & 7 & $3.00-3.14$ & $2.84-2.99$ \\
\hline $\mathrm{cyOOC}_{6} \mathrm{H}_{10} \mathrm{OOH}=\mathrm{OH}+\mathrm{cyOC}_{6} \mathrm{H}_{9} \mathrm{OOH}$ & DE2CKHP & $1000-3000$ & $1.50 \mathrm{E}+16$ & 0.0 & 42500 & $42 \mathrm{c}$ & $2.87-2.92$ & $2.77-2.82$ \\
\hline $\mathrm{cyC}_{6} \mathrm{H}_{11} \mathrm{O}=>\mathrm{CH}_{2} \mathrm{CHO}+2 \mathrm{C}_{2} \mathrm{H}_{4}$ & $\mathrm{DE}$ & $500-3000$ & $2.00 \mathrm{E}+13$ & 0.0 & 25700 & 5 & $9.6-10.1$ & $9.32-9.84$ \\
\hline \multicolumn{9}{|c|}{$\begin{array}{l}\text { Notes: } \\
* \text { Reaction rate constants in } \mathrm{cm}^{3} \text {, mol, cal units, } k=A T^{\beta} \exp (E / R T) \quad * * \text { No analysis done, due to limited of sources. } \\
\begin{array}{llll}\text { a) The pre-exponent factor, } A \text {,multiplied by } 1.33 & \text { b) Analogous with } C_{8}, A \text { multiplied by } 3.7, E_{a} \text { added by } 3.2 \mathrm{kcal} & \text { c) Analogous with } \mathrm{C}_{8}\end{array}\end{array}$} \\
\hline \multicolumn{9}{|c|}{$\begin{array}{l}\text { Abbreviations: } \\
\text { DE: Decomposition INT: Initiation HABS: H atom Abstraction RN: Ring-opening BSC: } \beta \text { - Scission ADD: Addition ISM: Isomerization } \\
\text { DE2BCYE: Decomposition to bi-cyclic ethers DE2CKHP: Decomposition to cyclic Ketohydroperoxide }\end{array}$} \\
\hline
\end{tabular}

\section{Results and discussion}

The behaviour of the high and low temperature cyclohexane oxidation model was validated and optimized based on a) the simulation of ignition delay times over the temperature range of $650-1700 \mathrm{~K}$ at various equivalence ratios and pressure ranges, b) Experimental data from Rapid Compression Machines (RCM) $)^{11,20}$ and shock tubes (ST) ${ }^{21}$ and c) laminar flame speed data ${ }^{12}$ at standard room pressure and temperature. PAH formation was observed in laminar premixed cyclohexane flames, ${ }^{6,16,22}$ see Table2 for details. The full sets of simulated data will be extensively presented in the full version of this work. In the following we present data in order to investigate the behaviour of the reaction model in high and low temperature range, at different pressures and at different compositions.

Table 3. Experimental data, used for validations.

\begin{tabular}{|c|c|c|c|}
\hline \multirow{2}{*}{ Exp. } & \multicolumn{3}{|c|}{ Validation } \\
\hline & ST & RCM & Flame Structure \\
\hline 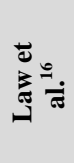 & & & $\begin{array}{l}\text { Concentration profile }^{\mathbf{1 5 , 1 6}} \\
\mathbf{T}=1000 \mathrm{~K}, \\
\mathbf{P}=30 \text { Torr, } \boldsymbol{\varphi}=1.0 \\
\text { Mixture: } \mathrm{CHX} / \mathrm{O}_{2} \text { in } 32.5 \% \mathrm{Ar} \\
\text { MFR }=0.00214 \mathrm{~g} \cdot \mathrm{cm}^{-2} \cdot \mathrm{s}^{-1}\end{array}$ \\
\hline 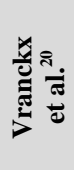 & & 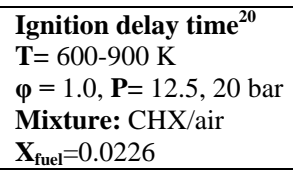 & \\
\hline 竎 & & $\begin{array}{l}\text { Ignition delay time } \\
\mathbf{P}=8,14 \text { bar } \\
\mathbf{T}=650-900 \mathrm{~K}, \boldsymbol{\varphi}=1.0 \\
\text { Mixture (CHX/ air) }\end{array}$ & \\
\hline
\end{tabular}

5

American Institute of Aeronautics and Astronautics 


\begin{tabular}{|c|c|c|}
\hline 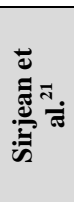 & $\begin{array}{l}\text { Ignition delay time } \\
\mathbf{T}=1230-1840 \mathrm{~K}, \\
\mathbf{P}=\sim 8 \mathrm{~atm} \\
\boldsymbol{\varphi}=0.5,1.0,2.0 \\
\text { Mixture: } \mathrm{CHX} / \mathrm{O}_{2} \text { in } \\
\text { 90.5-97.25\% Ar }\end{array}$ & \\
\hline 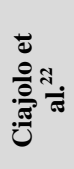 & & $\begin{array}{l}\text { Concentration profile } \\
\mathbf{T}=700 \mathrm{~K}, \\
\mathbf{P}=1 \mathrm{~atm}, \boldsymbol{\varphi}=2.33 \\
\text { Mixture: } \mathrm{CHX} / \mathrm{O}_{2} \text { in } 39.4 \% \mathrm{~N}_{2} \\
\text { MFR }=0.00283 \mathrm{~g} \cdot \mathrm{cm}^{-2} \cdot \mathrm{s}^{-1}\end{array}$ \\
\hline 氖 & & $\begin{array}{l}\text { Flame Speed } \\
\mathbf{T}=473 \mathrm{~K} \\
\mathbf{P}=0.1,0.3,0.6 \mathrm{MPa} \\
\text { Mixture (fuel-O2-N2) }\end{array}$ \\
\hline 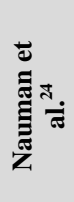 & $\begin{array}{l}\text { Ignition delay time } \\
\mathbf{T}=800-1400 \mathrm{~K}, \\
\mathbf{P}=\sim 16 \mathrm{~atm} \\
\boldsymbol{\varphi}=1.0 \\
\text { Mixture: } \\
\text { CHX/O2/ 89\% N2 }\end{array}$ & \\
\hline
\end{tabular}

\section{A. Ignition-delay-time}

The simulation of experimental data for ignition delay times of ${ }^{11}$ and $^{20}$ from Rapid Compression Machine (RCM) in the temperature range 650-900 $\mathrm{K}$ at $8 \mathrm{~atm}$ and $20 \mathrm{~atm}$ pressure are shown in Fig4. The measured data are reproduced successfully and under predicted uncertainty for the experimental data. However the negative temperature effects and the uprising of ignition delay time around 770-780 K, observed in both sets around, was not predicted by the model. With increase of temperature the direction of $\mathrm{cyC}_{6} \mathrm{H}_{11}+\mathrm{O}_{2}=\mathrm{cyC}_{6} \mathrm{H}_{11} \mathrm{OO}$ changes and the equilibrium will be shifted to the left side, which leads to the negative temperature behaviour. As a result, production of cycloalkyl radicals increases and consequently the level of olefins raises. Due to the implemented values for reaction rate constants in this sub-mechanism and thermodynamic properties provided by this model, existence of any turning point in the direction of the mentioned equilibrium in $700-800 \mathrm{~K}$ is not foreseen. Our further investigation shows that implementation of other suggested rate coefficients in literature in our sub-model, does not show any improvement in this case. Which other reaction paths are playing the key roles and could be applied in the model, would be one of the aims of our future cyclohexane kinetic research.

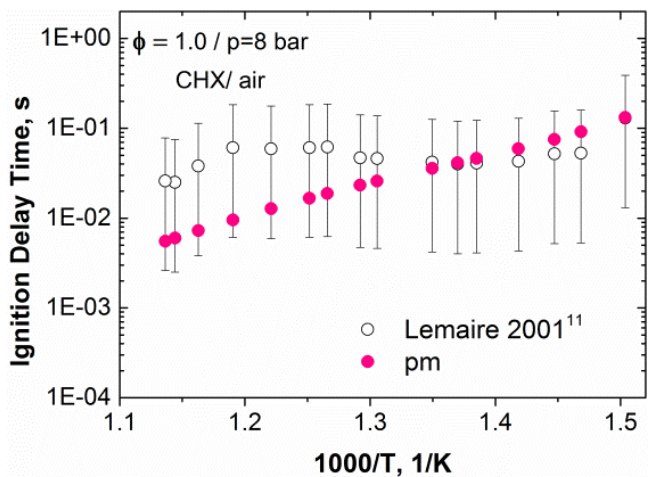

a

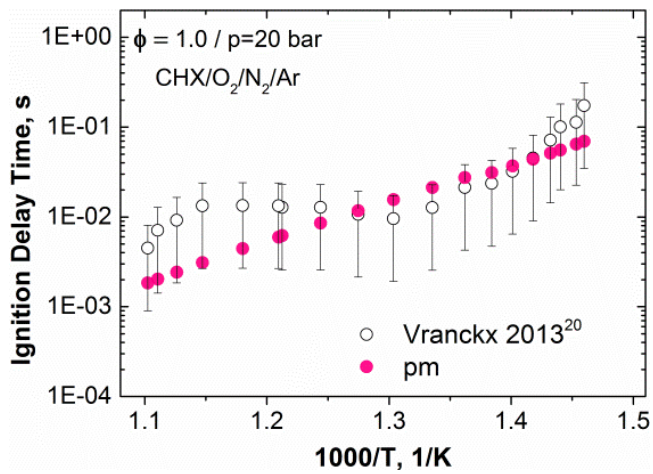

b

Figure 4. Cyclohexane ignition delay time from RCM experiments: a) Lemaire et al. ${ }^{11}$ for $\varphi=1, p=8$ bar and b) Vranckx, et al. (Aachen) ${ }^{20}$ at $\varphi=1.0, p=20$ bar. Closed colored symbols: Simulations, open symbols: experimental data with their uncertainties.

The experimental data from shock tube (ST) experiments under various circumstances and in different mixtures were also used for validation. Fig.5 shows the simulation versus experimental data for ignition delay times of ${ }^{19}{ }^{21}$ $\mathrm{and}^{24}$. The ignition delay data from shock tube experiments (depending on the conditions) have normally lower level of uncertainties compared to RCM experiments. The results are in a satisfactory agreement with experimental points both in high and normal pressure, and in different mixture fractions $(\varphi=0.5,1.0,2.0)$. Deviation of the predicted values are mainly less than the uncertainty considered for experiments. In contrary to low temperature results from RCM experiments, none of the studied ST experiments do not show the negative temperature behaviour and 
simulation results especially for low temperatures match perfectly with experiments. However, as Fig.5c shows the ignition delay time for temperature range of $1160-1260 \mathrm{~K}$ in lean condition $\varphi=0.5$ and pressure of 12 bar, were not well reproduced by the model and the values are slightly over predicted.
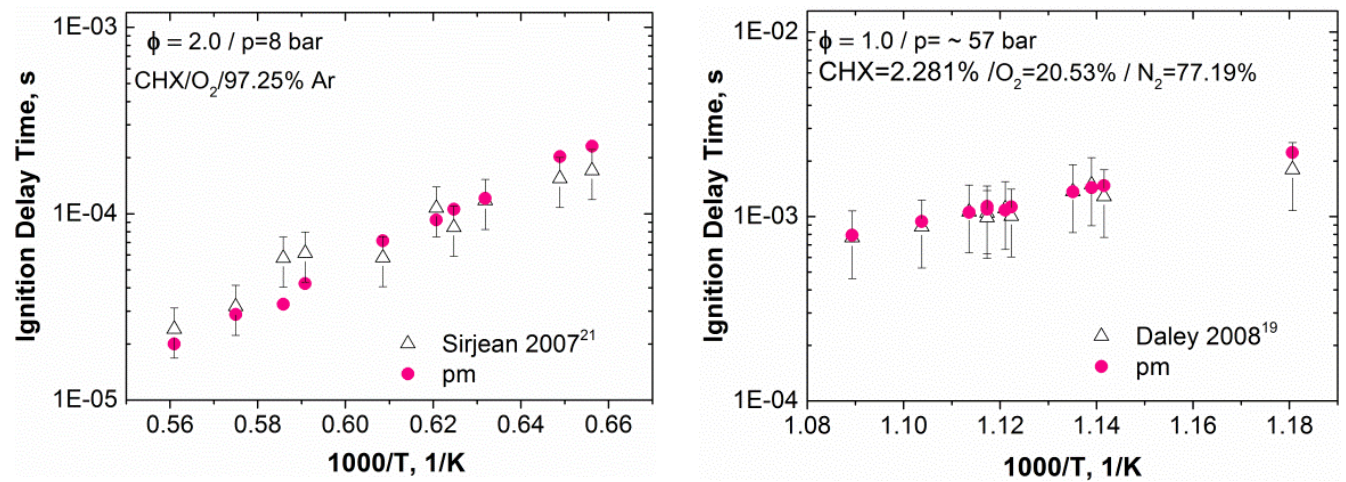

a

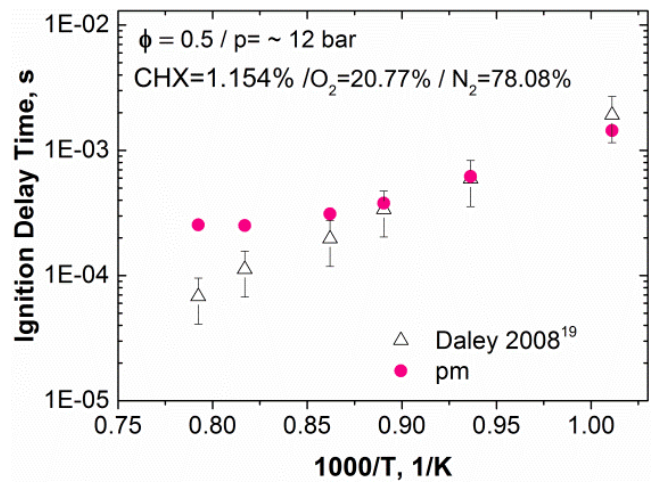

b

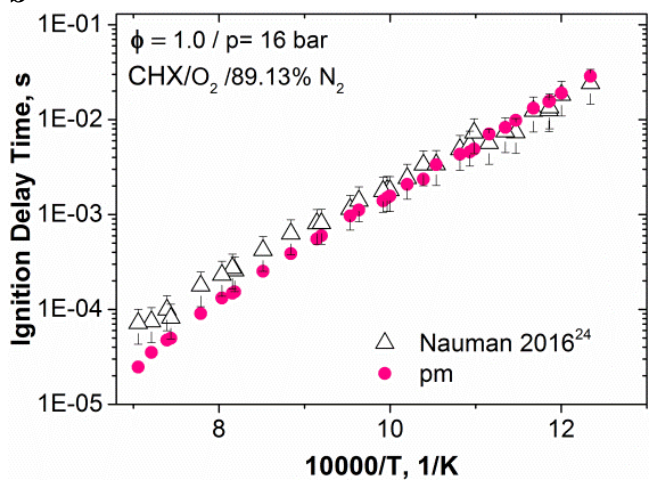

d

Figure 5. Cyclohexane ignition delay time from ST experiments: a) Sirjean et al. ${ }^{21}$ in $\varphi=2, p=8$ bar diluted in Ar; ST experiments from Daley et al. ${ }^{19}$, with $\mathrm{N}_{2}$ dilution, in $b$ ) stoichiometric situation, $p=57$ bar c) $\varphi=0.5$ and $p=12$ bar; d)Nauman et al. ${ }^{24}$ in $\varphi=1.0$ and $p=16$ bar. Closed colored symbols: Simulations, open symbols: experimental data with their uncertainties.

\section{B. Laminar-flame-velocity}

The flame speed values reported in ${ }^{23}$ at $\mathrm{p}=1 \mathrm{~atm}$ and in elevated temperature of $473 \mathrm{~K}$ were also used for validation. The results are presented in Fig.6.

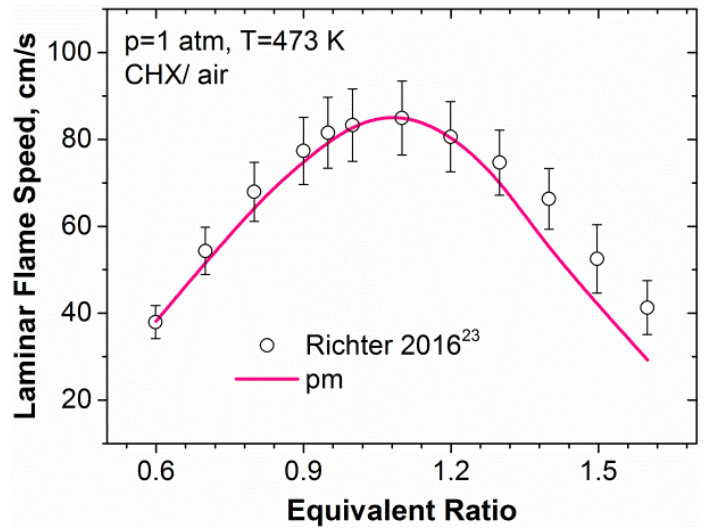

Figure 6. Cyclohexane laminar flame speed. The solid linesimulation; symbols- experimental data ${ }^{23}$. 
As it can be seen for $\varphi=0.5-1.3$ the simulation shows a perfect consistency with experimental data; as the ratio of fuel to oxidizer grows, the predicted values deviate slightly from experiment, however this should be taken into the account that the level of uncertainty of experiment grows, as the mixture goes richer.

\section{Concentration profiles}

Results of modeling the mole fraction profiles of some of the important $\mathrm{PAH}$ precursors, $\mathrm{C}_{3} \mathrm{H}_{6}, \mathrm{cyC}_{5} \mathrm{H}_{5}, \mathrm{cyC}_{5} \mathrm{H}_{6}$, cyC $_{6} \mathrm{H}_{9}$ and $\mathrm{C}_{6} \mathrm{H}_{6}$ (Or A1, benzene) ${ }^{6,16}$ at $\mathrm{p}=30$ Torr and $\varphi=1.0$ are shown in Fig.7a-k. Simulated and experimental values are in a proper consistency with each other. Concentrations of ${ }^{2} \mathrm{C}_{5} \mathrm{H}_{5}$ and $\mathrm{C}_{3} \mathrm{H}_{6}$ are over- predicted (see Fig.7g-h). Meanwhile, the concentration of $\mathrm{C}_{6} \mathrm{H}_{6}$ is by order of 10 is under estimated (Fig.7j). Also concentration of cyC ${ }_{6} \mathrm{H}_{9}$, predicted by the model is one order of magnitude above the observed values (Fig.7k). This means the model does not predict the sooting as high as observed by ${ }^{16}$, which sounds reasonable due to the low pressure of 30 Torr, stoichiometric condition of the premix flame, uncertainty of the temperature and location measurements.
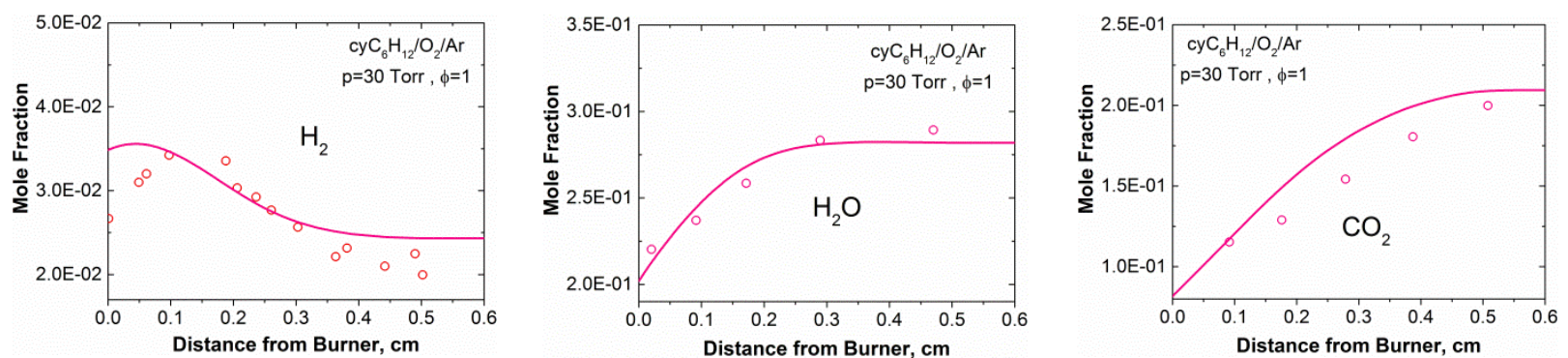

a

b
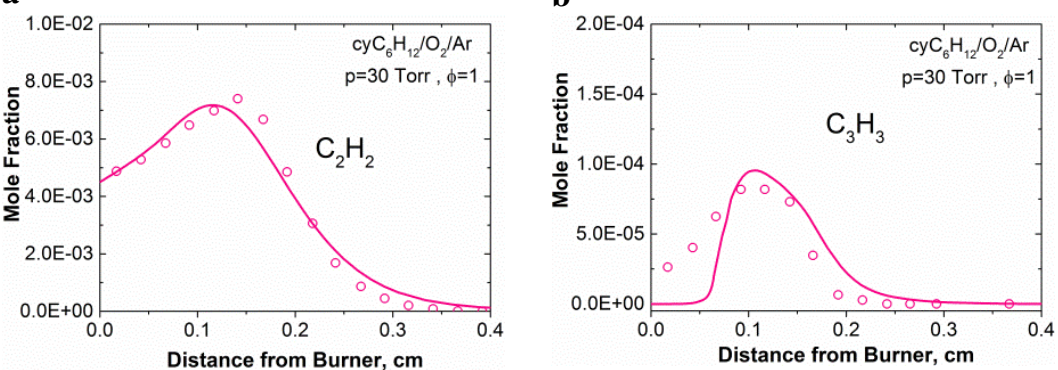

C

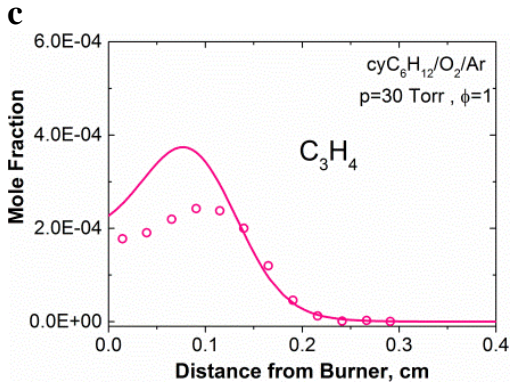

d

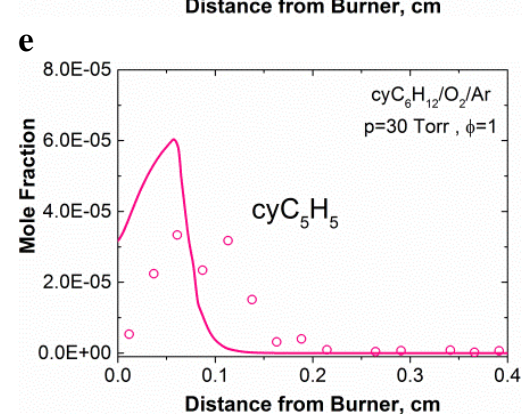

f

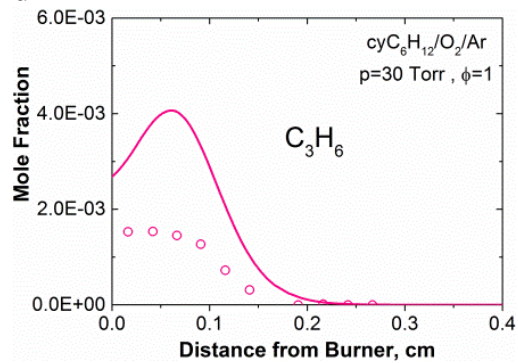

$\mathbf{h}$
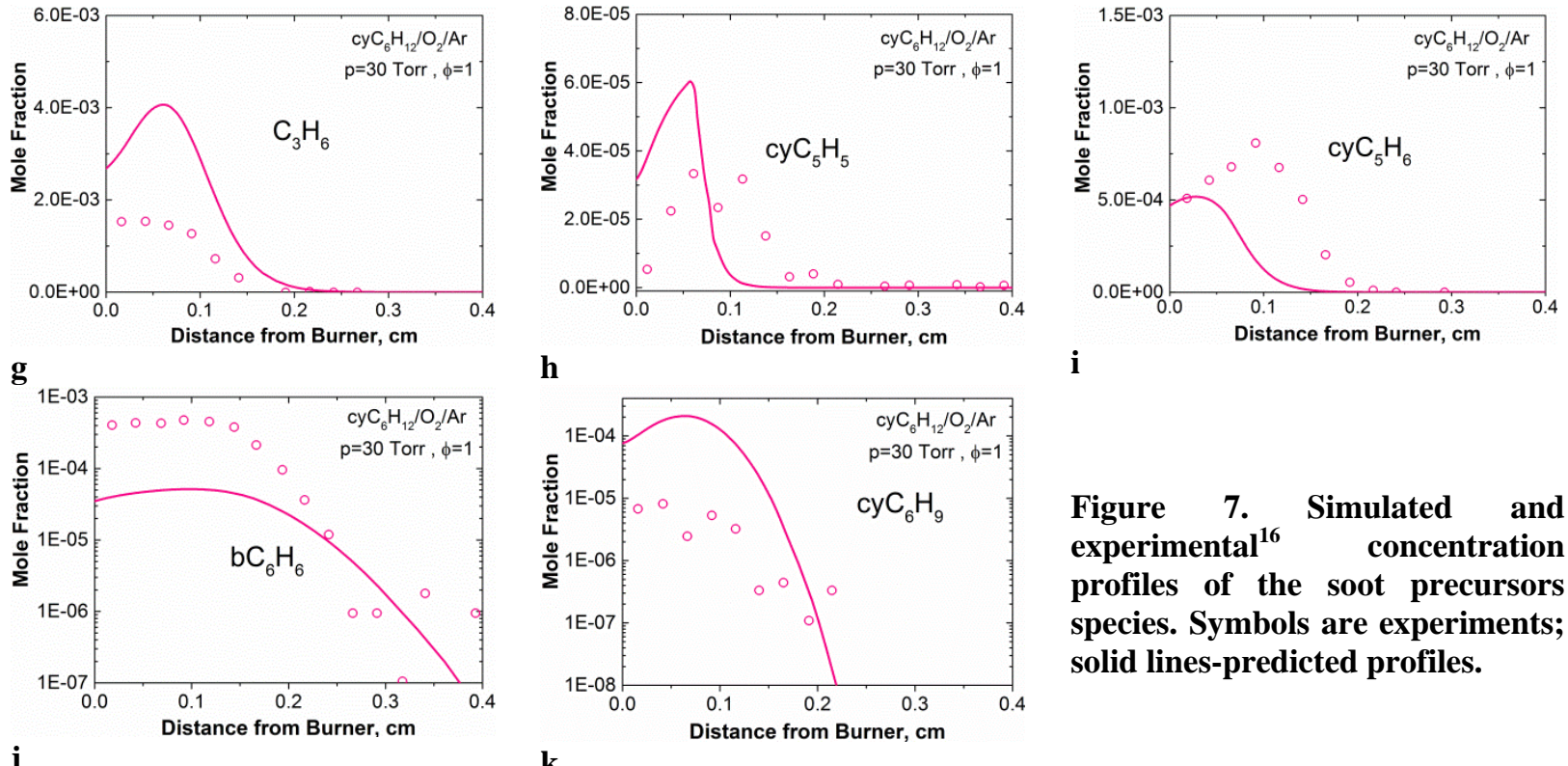

Figure 7. Simulated and experimental $^{16} \quad$ concentration $^{16}$ profiles of the soot precursors species. Symbols are experiments; solid lines-predicted profiles.

j

$\mathbf{k}$

The fuel-rich premixed flame $(\varphi=2.33)$ of ${ }^{22}$ was also simulated in atmospheric pressure and the concentration of the major species were compared with reported profiles. Fig.8a-i show these comparisons. The concentration 
profiles for reactants ( $\mathrm{cyC}_{6} \mathrm{H}_{12}, \mathrm{O}_{2}$ ), major products ( $\mathrm{CO}, \mathrm{CO}_{2}, \mathrm{H}_{2}, \mathrm{CH}_{4}$ and $\mathrm{C}_{2} \mathrm{H}_{2}$ ) (see Fig.8a-d) and also for certain intermediates such as $\mathrm{C}_{2} \mathrm{H}_{2}, \mathrm{C}_{4} \mathrm{H}_{6}$ and $\mathrm{C}_{3} \mathrm{H}_{4}$ are excellently reproduced by the model. However, mole fractions of $\mathrm{C}_{3} \mathrm{H}_{6}$ and cyC $_{5} \mathrm{H}_{6}$ are by factors around 3 and 10 respectively are over predicted. Unlikely to the previous data set of ${ }_{16}^{16}$, where the mole fraction of $\mathrm{C}_{6} \mathrm{H}_{6}$ was considerably under estimated, here the concentration of benzene is described around 10 times higher than observed in ${ }^{22}$. Fig.8i shows the concentration profiles for $\mathrm{C}_{4} \mathrm{H}_{2}$ and $\mathrm{C}_{4} \mathrm{H}_{4}$. The former is simulated higher than measured values by a factor 10 and the latter is significantly under experimental data. Investigating on the reasons for these mismatches could be a part of the further researches.
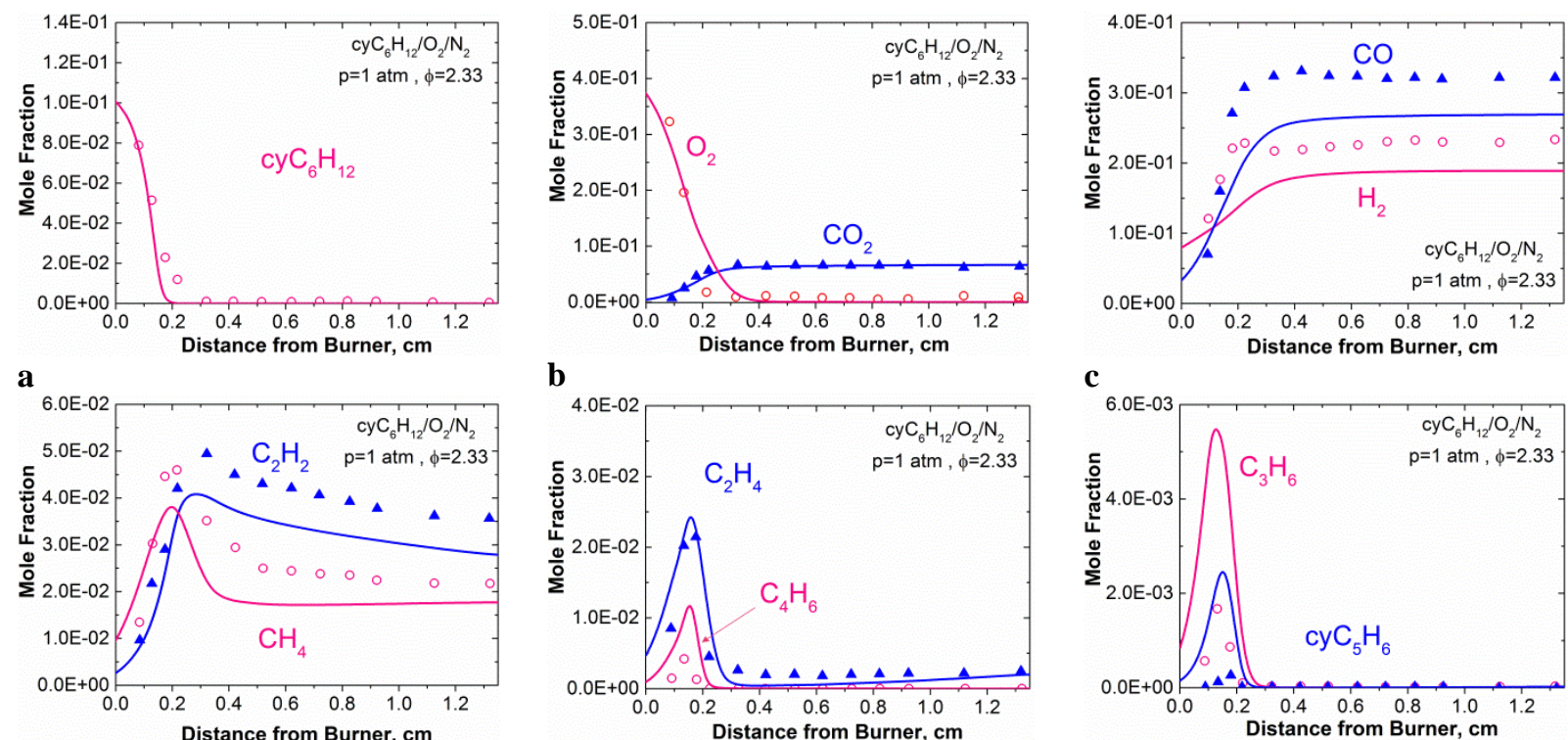

b
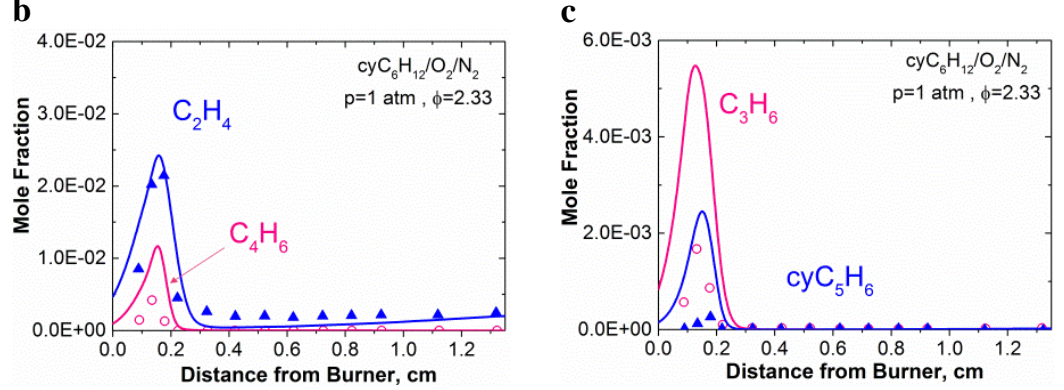

d

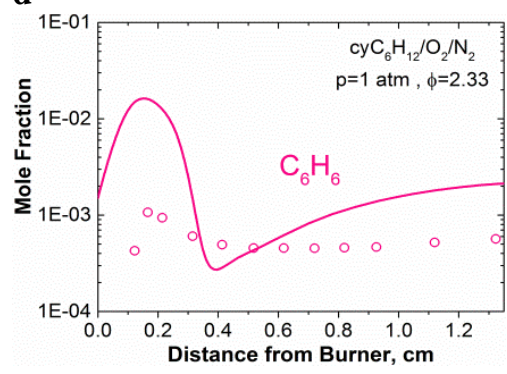

g

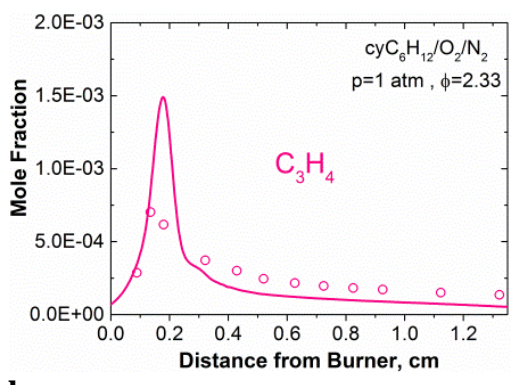

f

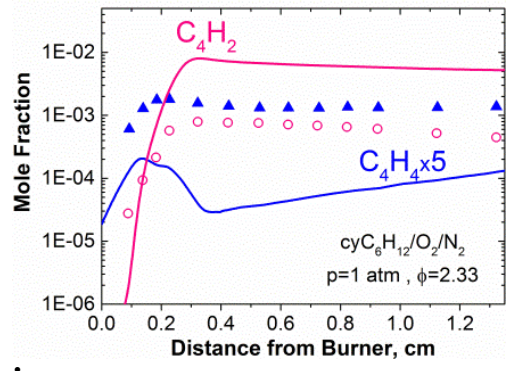

i

Figure 8. Simulated and experimental ${ }^{22}$ concentration profiles of the soot precursors species. Symbols are experiments; solid lines-predicted profiles.

\section{Conclusions}

A skeletal reaction mechanism for low and high temperature cyclohexane oxidation with PAH formation is reported. This mechanism is an extension of the DLR hydrocarbon reaction database by including the cycloalkane oxidation sub-model. The development of the mechanism was based on the data consistency and uncertainty analysis among the available literature data. The reaction model was successfully validated against experimental data for ignition delay times measured in rapid compression machines and shock tube experiments. Also, laminar flame specifications at low and atmospheric pressure and in stoichiometric and fuel-rich conditions were successfully validated. The important features of this mechanism are the new extended paths for both high and low temperature sub-mechanisms and its ability to predict the auto-ignition behavior in different conditions, as well as the laminar flame properties. The chemical pathways leading to intermediates and formation of PAH are well understood. 


\section{References}

${ }^{1}$ Voisin, D., Marchal, A., Reuillon, M., Boettner, J.-C., Cathonnet, M., "Experimental and Kinetic Modeling Study of Cyclohexane Oxidation in a JSR at High Pressure,” Combustion Science and Technology, Vol. 138, 1998, pp. 137-158.

${ }^{2}$ El Bakali A., Braun-Unkhoff, M., Dagaut, P., Frank, P., Cathonnet, M., "Detailed Kinetic Reaction Mechanism for Cyclohexane Oxidation at Pressure up to Ten Atmospheres,” Proceedings of the Combustion Institute, Vol. 28, 2000, pp. 16311638.

${ }^{3}$ Ristori, A., Dagaut, P., El Bakali, A., Cathonnet, M., “The Oxidation of N-Propylcyclohexane: Experimental Results and Kinetic Modeling,” Combustion Science and Technology, Vol. 165, 2001, pp. 197-228.

${ }^{4}$ Granata, S., Faravelli, T., Ranzi, E., “A wide range kinetic modeling study of the pyrolysis and combustion of naphthenes,” Combustion and Flame, Vol. 132, 2003, pp. 533-544.

${ }^{5}$ Dayma, G., Glaude, P. A., Fournet, R., Battin-Leclerc, F., "Experimental and Modeling Study of the Oxidation of Cyclohexene,” International Journal of Chemical Kinetics, Vol. 35, No. 7, 2003, pp. 273-285.

${ }^{6}$ Zhang, H. R., Huynh, L.K., Kungwan, N., Yang, Z., Zhang, S., "Combustion Modeling and Kinetic Rate Calculations for a Stoichiometric Cyclohexane Flame.1. Major Reaction Pathways,” J. Phys. Chem. A, Vol. 111, 2007, pp. 4102-4115.

${ }^{7}$ Cavallotti, C., Rota, R., Faravelli, T., Ranzi, E., “Ab initio evaluation of primary cyclo-hexane oxidation reaction rates,” Proceedings of the Combustion Institute, Vol. 31, 2007, pp. 201-209.

${ }^{8}$ Silke, E. J., Pitz, W. J., Westbrook, C. K., Ribaucour, M., “Detailed Chemical Kinetic Modeling of Cyclohexane Oxidation,” J. Phys. Chem. A, Vol. 111, 2007, pp. 3761-3775.

${ }^{9}$ Buda, F., Heyberger, B., Fournet, R., Glaude, P.A., Warth, V., Battin-Leclerc, F., "Modeling of the Gas-Phase Oxidation of Cyclohexane,” Energy \& Fuels, Vol. 20, 2006, 1450-1459.

${ }^{10}$ Serinyel, Z., Herbinet, O., Frottier, O., Dirrenberger, P., Warth, V., Glaude, P.A., Battin-Leclerc, F., “An experimental and modeling study of the low- and high-temperature oxidation of cyclohexane,” Combustion and Flame, Vol. 160, 2013, pp. 23192332.

${ }^{11}$ Lemaire, O., Ribaucour, M., Carlier, M., Minetti, R., "The Production of Benzene in the Low-Temperature Oxidation of Cyclohexane, Cyclohexene, and Cyclohexa-1,3-diene,” Combust and Flame,Vol. 127, 2001, pp. 1971-1980.

${ }^{12}$ Davis, S. G., Law, C. K., "Determination of and Fuel Structure Effects on Laminar Flame Speeds of $\mathrm{C}_{1}$ to $\mathrm{C}_{8}$ Hydrocarbons," Combustion Science and Technology, Vol.140, 1998, pp. 427-449.

${ }^{13}$ Dagaut, P., Cathonnet, M., Rouen, J. P., Foulatier, A., Quilgars, A., Boettner, J. C., Gaillard, F., James, H., “A jet-stirred reactor for kinetic studies of homogeneous gas-phase reactions at pressures up to ten atmospheres $(\approx 1 \mathrm{MPa})$," Journal of Physics E: Scientific Instruments, 19, 1986, pp. 207-209.

${ }^{14}$ Zeppieri, S., Brezinsky, K., Glassman, I., "Pyrolysis studies of methylcyclohexane and oxidation studies of methylcyclohexane and methylcyclohexane/toluene blends,” Combustion and Flame, Vol. 108 ,1997, pp. 266-286.

${ }^{15}$ Law, M. E., "Molecular-beam mass spectrometry of ethylene and cyclohexane flame,” Ph. D. Dissertation, Department of Chemical Engineering, University of Massachusetts Amherst, 2005.

${ }^{16}$ Law, M. E., Westmoreland, P. R., Cool, T. A., Wang, J., Hansen, N., Kasper, T., "Benzene precursors and Formation Routes in a Stoichiometric Cyclohexane Flame,” Proceedings of the Combustion Institute, Vol. 31, 2007, pp.565-573.

${ }^{17} \mathrm{Ji}, \mathrm{C}$., Dames, E., Sirjean, B., Wang, H., Egolfopoulos, F.N., “An experimental and modeling study of the propagation of cyclohexane and mono-alkylated cyclohexane flames," Proceedings of the Combustion Institute, Vol. 33, 2011, pp. 971-978.

${ }^{18}$ Wu, F., Kelley, A.P., Law, C.K., "Laminar flame speeds of cyclohexane and mono-alkylated cyclohexanes at elevated pressures,” Combust and Flame, Vol. 159, 2012, pp. 1417-1425.

${ }^{19}$ Daley, S.M., Berkowitz, A.M., Oehlschlaeger, M.A., “A Shock Tube Study of Cyclopentane and Cyclohexane Ignition at Elevated Pressures,” International Journal of Chemical Kinetics, Vol. 40, No. 10, 2008, pp. 624-634.

${ }^{20}$ Vranckx, S., Lee, C., Chakravarty, H.K. Fernandes, , R.X., “A rapid Compression Machine Study of the Low Temperature Combustion of Cyclohexane at Elevated Pressures, "Proceedings of the Combustion Institute, Vol. 34, 2012, pp. 377-384.

${ }^{21}$ Sirjean, B., Buda, F., Hakka, H., Glaude, P.A., Fournet, R., Warth, V., Battin-Leclerc, F., Lopez, M. R., “The Autoignition of Cyclopentane and Cyclohexane in a Shock Tube,” Proceedings of the Combustion Institute, Vol. 31, 2007, pp. 277-284.

${ }^{22}$ Ciajolo, A., Tergrossi, A., Mallardo, M., Faravelli, T., Ranzi, E., "Experimental and Kinetic Modeling Study of Sooting Atmospheric-Pressure Cyclohexane Flame,” Proceedings of the Combustion Institute, Vol. 32 , 2009, pp. 585-591.

${ }^{23}$ Richter, S., Raida, M. B., Naumann, C., Riedel, U., "Measurement of the Laminar Burning Velocity of Neat Jet Fuel Components,” Proceedings of the World Congress on Momentum, Heat and Mass Transfer (MHMT'16), Paper No. CSP 115, Prague-Czech Republic, April 2016.

${ }^{24}$ Naumann, C. et al.,“InnoTreib - Innovative Treibstoffe der Zukunft,” Bundesministerium für Wirtschaft und Energie (BMWi), Interim reports AP 4.2 and AP 6 from 05.08.2016, Rept. FKZ 20E1310, 2016.

${ }^{25}$ Tsang, W., “Thermal Stability of Cyclohexane and 1- Hexene,” J. Phys. Chem. Ref. Data, Vol. 10, 1978, pp. 1119-1138.

${ }^{26}$ Zeelenberg A. P., Bruijn H. W., "Kinetics, Mechanism and Products of the Gaseous Oxidation of Cyclohexane,”Combust and Flame, Vol. 9, 1965, pp. 281-295.

${ }^{27}$ Klaï, S. E., Baronnet, F., “Etude de l'oxydation homogene du cyclohexane en phase Gazeuse,” J. Chim. Phys., Vol. 90, 1993, pp. 1951-1998.

${ }^{28}$ Sirjean, B., Glaude, P. A., Ruiz-Lopèz, M. F., Fournet, R. "Theoretical Kinetic Study of Thermal Unimolecular Decomposition of Cyclic Alkyl Radicals,” J. Phys. Chem. A,Vol. 112, 2008, No.46, pp. 11598-11610. 
${ }^{29}$ Hoyermann, K., Maarfeld, S., Nacke, F., Nothdurft, J., Olzmann, M., Wehmeyer, J., Welz, O., Zeuch, T., “Rate Coefficients for Cycloalkyl + O Reactions and Product Branching in the Decomposition of Chemically Activated Cycloalkoxy Radicals: an Experimental and Theoretical Study,” Phys. Chem. Chem. Phys., Vol. 12, 2010, pp. 8953-8967.

${ }^{30}$ Slavinskaya, N. A., Wacker, M., "Kinetic Modeling of Cyclohexane Oxidation with PAH Formation”, European Combustion Symposium, Wien, April, 14-17, 2009.

${ }^{31}$ Slavinskaya, N. A., Frank, P., “A Modelling Study of Aromatic Soot Precursors Formation in Laminar Methane and Ethene Flames,” Combust and Flame, Vol. 156 ,2009, pp. 1705-1722.

${ }^{32}$ Chernov, V., Thomson, M. J., Dworkin, S. B., Slavinskaya, N. A., Riedel, U., "Soot Formation with $\mathrm{C}_{1}$ and $\mathrm{C}_{2}$ Fuels Using an Improved Chemical Mechanism for PAH Growth,” Combust and Flame, Vol. 161, 2014, pp. 592-60.

${ }^{33}$ Abbasi, M., Slavinskaya, N. A., Riedel, U., "Uncertainty of Thermo-Chemical Properties of Species Related to Cyclohexane Low Temperature Oxidation,” DLR (German Aerospace Center) Archive, Chemical Kinetic Dept., Stuttgart, Germany, April 2016, (unpublished).

${ }^{34}$ Weber, B. W., Pitz, W. J., Mehl, M., Silke, E. J., Davis, A. C., Sung, C. J., "Experiments and modeling of the autoignition of methylcyclohexane at high pressure,” Combustion and Flame, Vol. 161,2014, pp. 1972-1983.

${ }^{35}$ Ranzi, E., Frassoldati, A., Grana, R., Cuoci, A., Faravelli, T., Kelley, A. P., Law, C. K., "Hierarchical and comparative kinetic modeling of laminar flame speeds of hydrocarbon and oxygenated fuels," Progress in Energy and Combustion Scienc,Vol. 38, 2012, pp. 468-501.

${ }^{36}$ Miyoshi, A., Tsuchiya, K., Yamauchi, N., Matsui, H., “Reactions of Atomic Oxygen (3P) with Selected Alkanes,” J. Phys. Chem., Vol. 98, 1994, pp. 11452-11458.

${ }^{37}$ Cohen, N., Westberg, K. R., "The use of transition-state theory to extrapolate rate coefficients for reactions of O atoms with alkanes,” Int. J. Chem. Kinet. Vol. 18, 1986, pp. 99.

${ }^{38}$ Knepp, A. M., Meloni, G., Jusinski, L. E., Taatjes, C. A., Cavallotti, C., Klippenstein, S. J. “Theory, measurements, and modeling of $\mathrm{OH}$ and $\mathrm{HO}_{2}$ formation in the reaction of cyclohexyl radicals with $\mathrm{O}_{2}$," Phys. Chem. Chem. Phys., Vol. 9, 2007, pp. 4315-4331.

${ }^{39}$ Stuckey, W. K., Heicklen, J., “Some Reactions of Oxygen Atoms. III. Cyclopropane, Cyclobutane, Cyclopentane, and Cyclohexane,” The Journal of Chemical Physics, Vol. 46 1967, pp. 4843.

${ }^{40}$ Kurbatov, V.S., Silin, I. N., "New method for minimizing regular functions with constraints on parameter region” Nucl. Instrum. Methods,. Vol. A 345, 1994, pp. 346-350.

${ }^{41}$ Washida, N., Takagi, H., "Reaction of Cyclohexane and Cyclohexyl Radicals with Atomic and Molecular Oxygen,” J. Am. Chem. Soc. Vol. 10,1982, pp.168-173.

${ }^{42}$ Ranzi, E., Faravelli, T., Gaffuri,P., Sogaro, A., “A Wide-Range Modeling Study of Iso-Octane Oxidation,” Combustion and Flame, Vol. 108, 1997, pp. 24-42.

${ }^{43}$ Curran, H. J., Gaffuri, P., Pitz, W. J., Westbrook, C. K., “A Comprehensive Modeling Study of iso-Octane Oxidation,” Combustion and Flame, Vol. 129, 2002, pp. 253-280.

${ }^{44}$ Joback, K.G., Reid, R.C., "Estimation of Pure-Component Properties from Group-Contributions,” Chemical Engineering Communications, Vol. 57, 1987, pp. 233-243. 